УДК $544.723 .2: 634.21$

\title{
ГАЛИШ Вїа,
}

к. х. н., стариий викладач кафедри екологї та технологї рослинних полімерів Національного технічного університету Украӥни

"Київсъкий політехнічний інститут імені Ігоря Сікорсъкого"

\section{ЧИКУН Надія,}

стариий викладач кафедри товарознавства,

управління безпечністю та якістю

Київського національного торговельно-економічного університету

\section{ПАСАЛЬСЬКИЙ Богдан,}

к. х. н., доцент кафедри товарознавства,

управління безпечністю та якістю

Київького національного торговельно-економічного університету

\section{СОРБЦІЙНІ ВААСТИВОСТІ ШКАРАМУПИ КІСТОЧОК АБРИКОСА}

Досліджено сорбиійні властивості рослинних відходів харчової промисловості, зокрема шкаралупи кісточок абрикоса. Визначено сорбиійну здатність рослинного матеріалу щодо метиленового синього та йонів важких металів $\left(\mathrm{Fe}^{3+} \mathrm{ma} \mathrm{Cu}^{2+}\right)$. Показано, що за поглинальними властивостями подрібнена шкаралупа не поступається за ефективністю, а в деяких випадках навіть перевищує інших представників рослинних відходів сільського господарства та харчової промисловості.

Ключові слова: лігноцелюлоза, барвник, йони важких металів, целюлоза, лігнін, сорбція, ефективність сорбції.

Гальщи В., Чикун Н., Пасальский Б. Сорбционные свойства скорлупь косточек абрикоса. Исследованы сорбиионные свойства растительных отходов пищевой промышленности, в частности скорлупы косточек абрикоса. Определена сорбционная способность растительного материала $\kappa$ метиленовому синему и ионам тяжельх металлов $\left(\mathrm{Fe}^{3+} u \mathrm{Cu}^{2+}\right)$. Показано, что по поглощуающим свойствам измельченная скорлупа не уступает по эффективности, а в некоторых случаях даже превосходит других представителей растительных отходов сельского хозяйства и пищевой промышленности.

Ключевые слова: лигноцеллюлоза, краситель, ионы тяжелых металлов, целлюлоза, лигнин, сорбция, эффективность сорбции.

Постановка проблеми. Розробка нових і модернізація існуючих способів і шляхів вирішення екологічних проблем, пов'язаних із забрудненням навколишнього середовища різними токсикантами, $\epsilon$ пріоритетним завданням сучасної природоохоронної діяльності в умовах стрімкого індустріального та промислового розвитку. Щорічно в результаті техногенного забруднення відбувається потрапляння

(C) Галиш Віта, Чикун Надія, Пасальський Богдан, 2018 
до водних об'єктів і накопичення важких металів та синтетичних барвників. Йони важких металів $є$ токсичними й можуть призводити до сильної інтоксикації організму, а також спричиняти різні захворювання [1;2]. Синтетичні барвники також можуть завдавати непоправної шкоди екосистемі, оскільки є токсичними, канцерогенними й мутагенними [3; 4]. 3 метою зменшення антропогенного навантаження на екосистему потрібним $\epsilon$ впровадження та розвиток раціонального природокористування, застосовування маловідходних і безвідходних виробництв. Зазначені заходи спрямовано на екологізацію виробництв i на поліпшення стану навколишнього середовища, що є важливим i необхідним з боку охорони здоров'я населення.

Аналіз останніх досліджень і публікацій. Сорбційні технології розглядаються як найефективніший процес для видалення йонів металів зі стічних промислових вод. Біосорбція - перспективний процес, що може застосовуватися для видалення забруднюючих речовин із водних розчинів 3 використанням недорогих сорбентів на основі рослинних відходів деревообробної, целюлозно-паперової промисловості та сільського господарства, про що свідчать дослідження В. М. Осокіна, В. А. Соміна [5], А. Bazargan, J. Tan та ін. [6]. Основні переваги використання сорбентів - щорічна відновлюваність, доступність, дешевизна та легкість утилізації. Рослинні відходи - це лігноцелюлозний біополімерний комплекс, який складається переважно з полісахаридної (холоцелюлоза) та ароматичної (лігнін) складової, а також мінеральних і екстрактивних речовин, вміст яких визначає сорбційні властивості природних матеріалів.

Перспективним $є$ використання як сорбентів твердих рослинних відходів харчової промисловості, які утворюються в значних обсягах i не знаходять широкого практичного використання. На сьогодні найбільш поширеним способом переробки шкаралупи кісточок $є$ карбонізація, унаслідок чого, як показано в роботі I. Ozdemir, M. Sahin, R. Orhan, M. Erdem [7], отримують вуглецеві сорбенти, вихід яких є дуже низьким (менше 30 \%). Інший спосіб одержання сорбентів 3 відходів харчової промисловості, запропонований А. А. Ніколайчук, передбачає гідроліз подрібнених кісточок кислотою з подальшою активацією розчином лугу [8]. Унаслідок такої обробки отримують сорбент 3 виходом менше $40 \%$. Невирішеною залишається проблема низької поглинальної здатності таких матеріалів щодо органічних речовин.

Рослинні матеріали в необробленому вигляді здатні зв'язувати органічні та неорганічні речовини за рахунок поверхневої адсорбції, а також хімічної взаємодії 3 функціональними групами лігніну, целюлози, геміцелюлоз. Для підвищення сорбційної здатності рослинних матеріалів можна використовувати механічний спосіб активування (подрібнення), що уможливлює збільшити питому поверхню та кількість доступних функціональних груп. 
Мета роботи - визначення хімічного складу шкаралупи кісточок абрикоса та дослідження їх сорбційної здатності в подрібненому стані щодо синтетичного барвника та йонів металів.

Матеріали та методи. Використано подрібнені до розмірів 0.5-1 мм шкаралупи кісточок абрикоса, що $є$ багатотоннажним відходом консервної промисловості. Хімічний склад вихідного матеріалу визначено відповідно до стандартних методик, які використовуються в целюлозно-паперовій промисловості [9].

Інфрачервоний спектр (ІЧ-спектри) реєстрували на спектрофотометрі Specord M80 (Carl Zeiss, Німеччина) в діапазоні 300-4000 см-1. Підготовка зразка до досліджень полягала в розтиранні матеріалу з KBr у співвідношенні 1:100 з подальшим пресуванням у таблетки.

Питому площу поверхні сировини визначено адсорбцією азоту за температури $-272{ }^{\circ} \mathrm{C}$ на аналізаторі NOVA 2200 (Quantachrome, США). Ртутну порометрію проведено на PoreMaster 33 (Quantachrome, США). Питому площу поверхні визначено сорбцією метиленового синього, об'єм пор матеріалу - адсорбцією парів бензену в ексикаторі [10].

Сорбцію метиленового синього досліджено за температури $25^{\circ} \mathrm{C}$ із використанням модельних розчинів барвників із концентраціями 5-500 мг/дм ${ }^{3}$. Наважка сорбенту -0.20 г, об'єм розчину $-50 \mathrm{~cm}^{3}$. Вихідну й рівноважну концентрації барвників визначено спектрофотометричним методом. Спектри пропускання розчинів реєстрували на Specord M40 (Carl Zeiss, Німеччина) за довжини хвилі 664 нм.

Поглинальну здатність рослинного матеріалу щодо йонів $\mathrm{Fe}^{3+}$ i $\mathrm{Cu}^{2+}$ визначено в статичних умовах. Сорбцію проведено з модельних розчинів солей $\mathrm{NH}_{4} \mathrm{Fe}\left(\mathrm{SO}_{4}\right)_{2} \cdot 12 \mathrm{H}_{2} \mathrm{O}$ i $\mathrm{CuSO}_{4} \cdot 5 \mathrm{H}_{2} \mathrm{O}$ з концентраціями зазначених катіонів $10-50$ та $50-250 \mathrm{Mг} /$ дм $^{3}$ відповідно, наважка сорбенту при цьому становила 0.5 г, об'єм розчину $-50 \mathrm{~cm}^{3}$, тривалість сорбції - 30 хв. Концентрації вихідних і розчинів після сорбції йонів $\mathrm{Fe}^{3+}$ визначено спектрофотометричним методом за довжини хвилі 510 нм, а йонів $\mathrm{Cu}^{2+}$ - йодометричним методом [11].

Результати дослідження. Результати визначення хімічного складу шкаралупи кісточок абрикоса наведено в табл. 1, які свідчать про те, що основними компонентами досліджуваної сировини $\epsilon$ полісахаридна (холоцелюлоза) та ароматична (лігнін) складова. Аналіз складу рослинних відходів сільського господарства та харчової промисловості показує, що вміст холоцелюлози в шкаралупі абрикоса близький до вмісту того ж компонента в шкаралупі фруктових кісточок і горіхів, однак менший, ніж в шкаралупі круп i качанах кукурудзи. Шкаралупа фруктових кісточок і горіха характеризується більшим вмістом лігніну. Вміст речовин, що екстрагуються спиртобензеновою сумішшю, $\epsilon$ найбільшим у представників рослинних відходів сільського господарства. Такі речовини, як відомо, лімітують дифузію реагентів у міжклітинний простір рослинних матеріалів. 
Мінеральні речовини рослинних відходів сприяють утворенню сорбційних матеріалів з розвиненою пористою структурою, що має позитивний вплив на адсорбційну здатність. Вміст неорганічних речовин в шкаралупі кісточок абрикосу $€$ найменшим порівняно 3 іншими рослинними матеріалами.

Таблиия 1

Хімічний склад шкаралупи кісточок абрикоса та інших відходів харчової промисловості й сільського господарства [12]

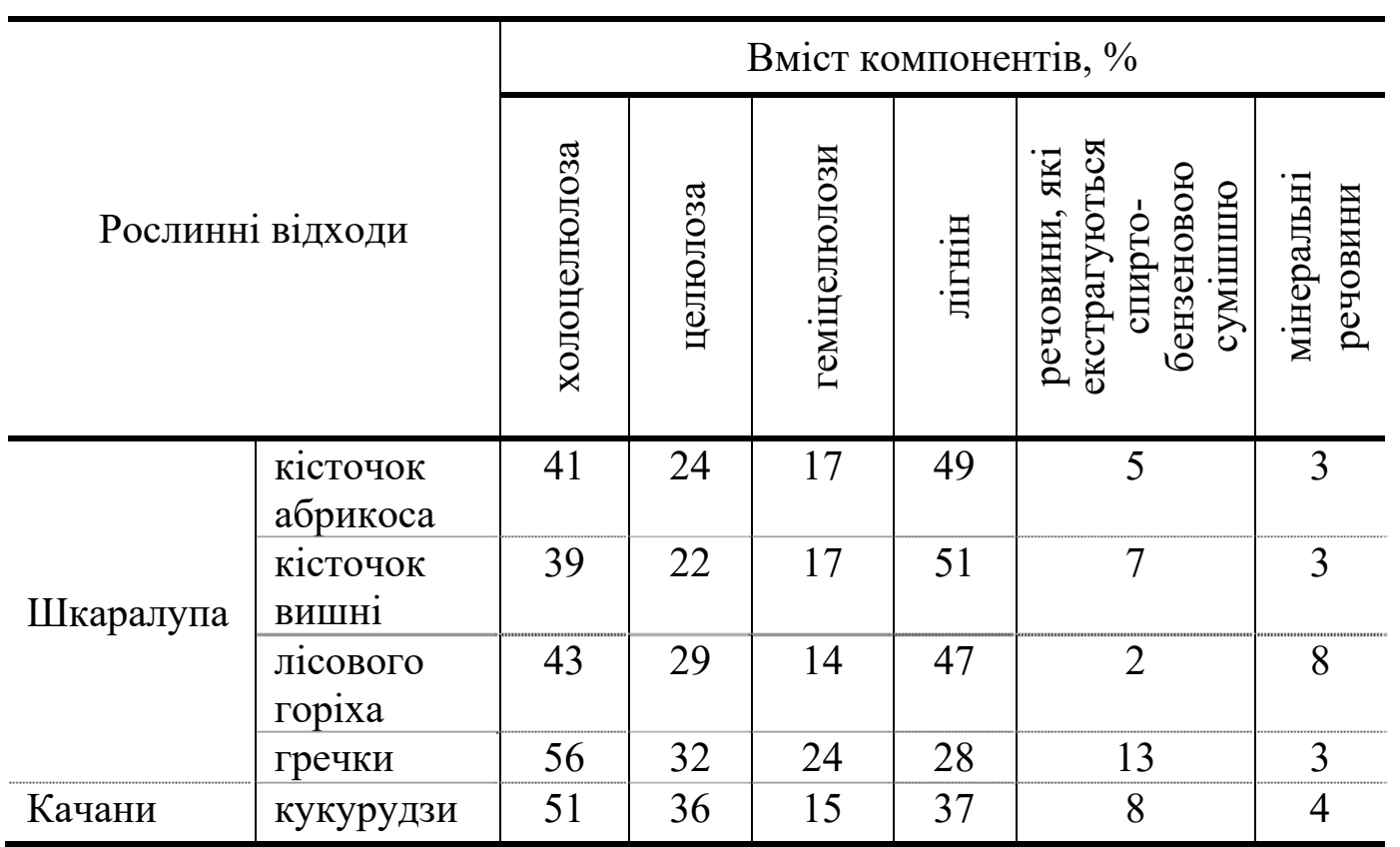

Результати ГЧ-спектроскопії досліджуваного зразка наведено на puc. 1. Широка смуга поглинання в зоні 3000-3700 см-1 відноситься до валентних коливань водневих зв'язків спиртових і фенольних гідроксильних лігніну та целюлози. Смуга поглинання при $2900 \mathrm{~cm}^{-1}$ відповідає симетричним й асиметричним валентним коливанням $\mathrm{C}-\mathrm{H}$ зв'язків в $-\mathrm{CH}_{3}$ та метиленових $-\mathrm{CH}_{2}-$ групах. Смуга поглинання при $1747 \mathrm{~cm}^{-1}$ відповідає валентним коливанням $\mathrm{C}=\mathrm{O}$ груп. Деформаційні коливання $\mathrm{H}-\mathrm{O}-\mathrm{H}$ кристалізаційної води спостерігаються при $1635 \mathrm{~cm}^{-1}$. До скелетних валентних коливань $\mathrm{C}=\mathrm{C}$ ароматичного кільця структурних одиниць лігніну відносять характерні смуги поглинання при 1508, 1468 та $1423 \mathrm{~cm}^{-1}$. Дві полоси поглинання, що містяться в зоні 1325-1378 $\mathrm{cm}^{-1}$, свідчать про деформаційні коливання в О-Н зв'язків фенолів.

Результати дослідження поверхневих властивостей свідчать про те, що значення питомої поверхні шкаралупи кісточок абрикоса за методами адсорбції азоту та ртутної порометрії є близькими $-5 \mathrm{i} 7 \mathrm{~m}^{3} / \Gamma$ відповідно. Більше значення вказаного параметра, одержане за результатами адсорбції метиленового синього $\left(27 \mathrm{~m}^{3} / \Gamma\right)$, можна пояснити тим фактом, що фіксація барвника на поверхні рослинних матеріалів відбувається не тільки за рахунок адсорбції в порах, а й за рахунок 
хімічної взаємодії катіонів барвників і функціональних груп лігніну та целюлози. Також відбувається набухання природних полімерів у водному розчині барвника. Отримані дані об'єму адсорбційних пор за бензеном є дуже низькими $-0.03 \mathrm{~cm}^{3} /$ г.

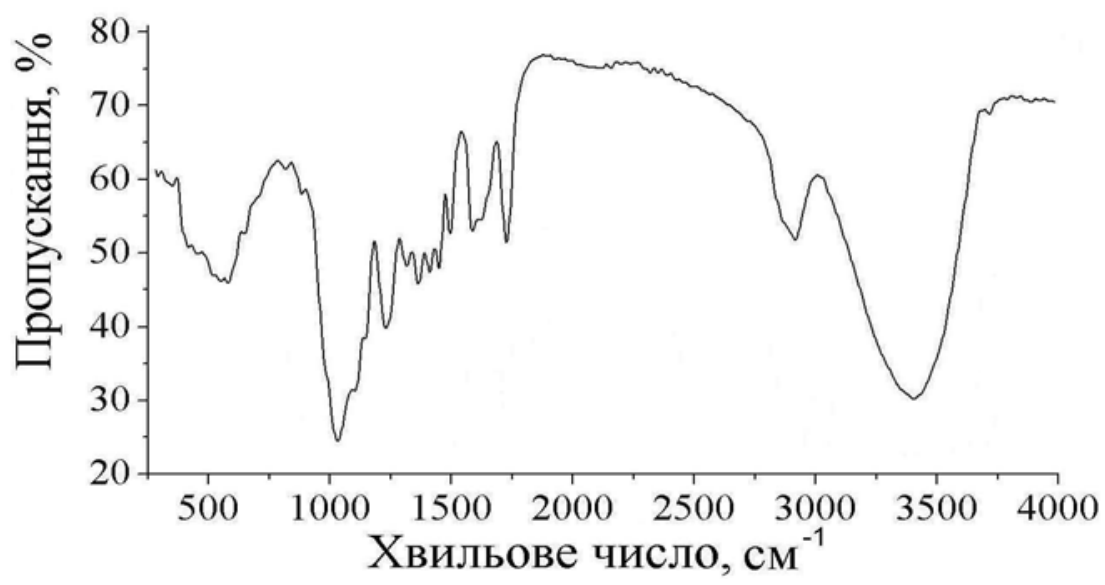

Puc. 1. ІЧ-спектр шкаралупи кісточок абрикоса

Рослинні матеріали завдяки наявності функціональних груп різної природи (метоксильних, гідроксильних, карбонільних та ін.), що містяться як в лігніні, так і полісахаридній складовій, можуть проявляти сорбційні властивості щодо органічних і неорганічних речовин.

Дослідження впливу тривалості процесу сорбції на іiі ефективність проведено на прикладі водного розчину метиленового синього (puc. 2).

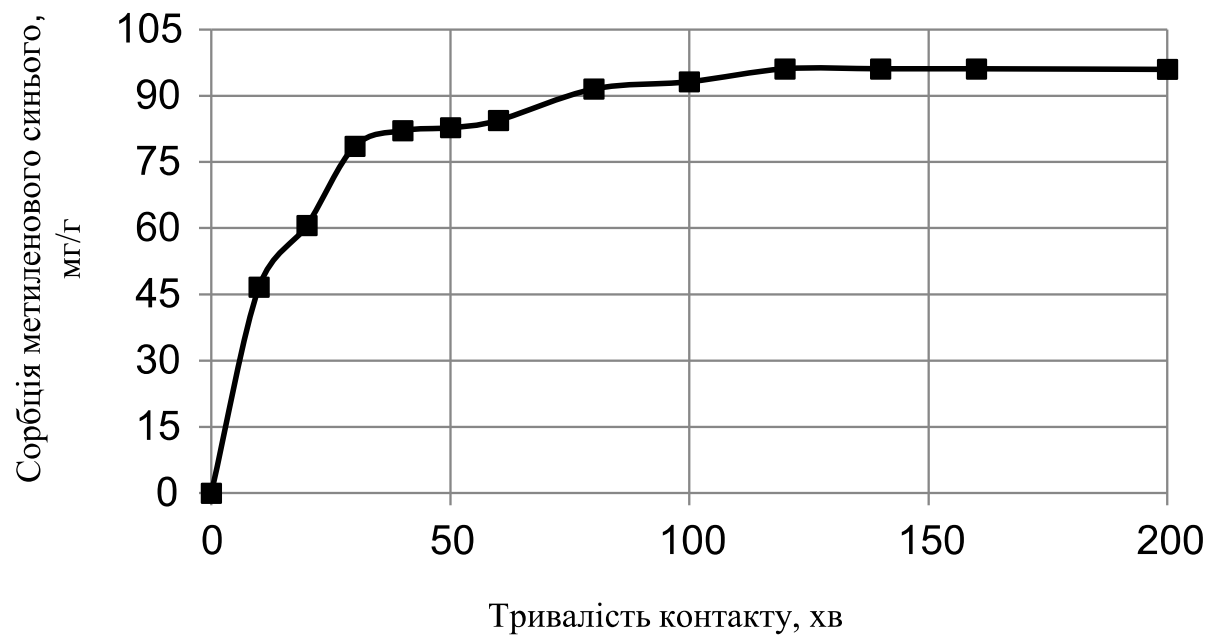

Рис. 2. Залежність сорбції метиленового синього від тривалості контакту

Одержані результати свідчать, що максимальна швидкість поглинання барвника відповідає першим 10 хв контакту, повна сорбційна рівновага досягається протягом 120 хв. 
Результати визначення сорбційної здатності вихідного матеріалу щодо органічних барвників показують, що сорбційна ємність подрібненої шкаралупи кісточок абрикоса щодо метиленового синього сягає 49 мг/г (рис. 3).

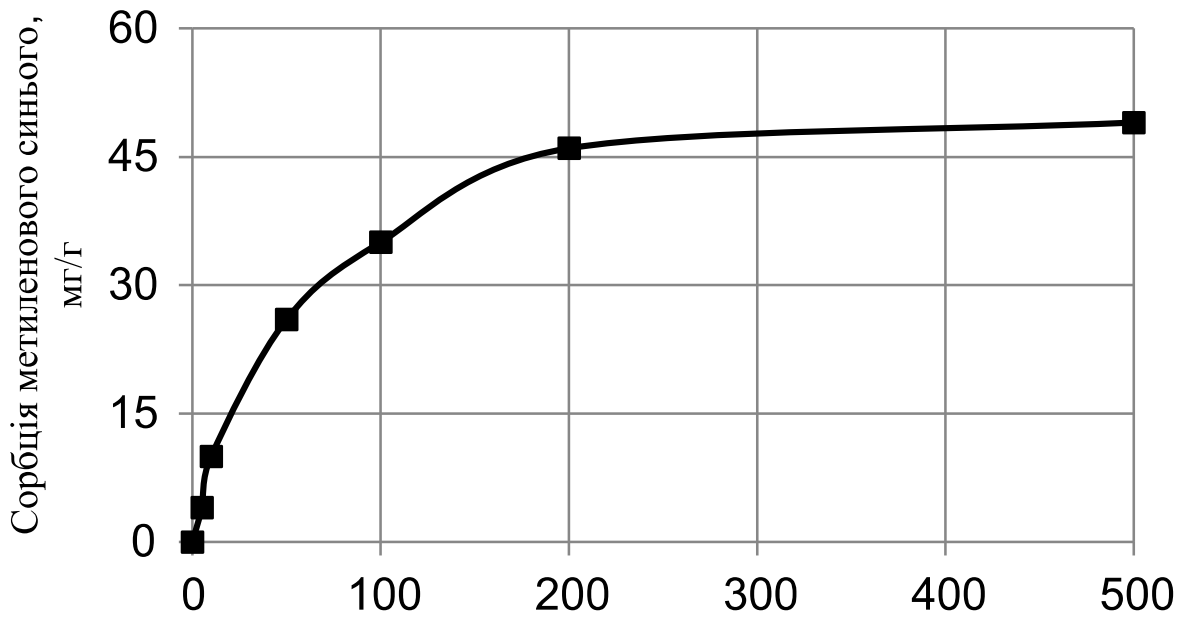

Концентрація барвника в розчині, мг/дм³

Рис. 3. Залежність сорбції метиленового синього від концентрації барвника в розчині

Порівняння отриманих даних 3 літературними свідчить про те, що за значенням сорбційної ємності щодо метиленового синього досліджуваний матеріал дуже близький до інших відходів сільського господарства та харчової промисловості. Максимальна сорбційна ємність подрібненої шкаралупи кісточок абрикоса щодо йонів $\mathrm{Fe}^{3+}$ та $\mathrm{Cu}^{2+}$ становить 44 та 54 мг/г відповідно (рис. 4 a, б). Отримані результати вказують на те, що досліджуваний матеріал характеризується високою сорбційною здатністю щодо йонів металів порівняно 3 іншими представниками рослинних відходів (табл. 3).

Таблиия 3

Сорбційні властивості рослинних відходів

\begin{tabular}{|c|c|c|c|}
\hline Матеріал & $\begin{array}{l}\text { Об’єкт } \\
\text { сорбції }\end{array}$ & $\begin{array}{c}\text { Сорбційна } \\
\epsilon \text { мність, мг/Г }\end{array}$ & Джерело \\
\hline Оболонка насіння соняшнику & \multirow{4}{*}{$\begin{array}{c}\text { Метиленовий } \\
\text { синій }\end{array}$} & 35.4 & \multirow{2}{*}[13]{} \\
\hline Качани кукурудзи & & 33.6 & \\
\hline Шкірка ананаса & & 64.4 & Г14] \\
\hline Шкірка апельсина & & 48.3 & {$[14]$} \\
\hline Шкірка апельсина & \multirow{5}{*}{$\begin{array}{l}\mathrm{Fe}^{3+} \\
\mathrm{Cu}^{2+}\end{array}$} & 13.3 & {$[15]$} \\
\hline Шкаралупа лісового горіха & & 13.6 & {$[16]$} \\
\hline Солома ячменю & & 4.6 & [17] \\
\hline Шкаралупа арахісу & & 25.4 & [18] \\
\hline Кісточки винограду & & 3.4 & [19] \\
\hline
\end{tabular}




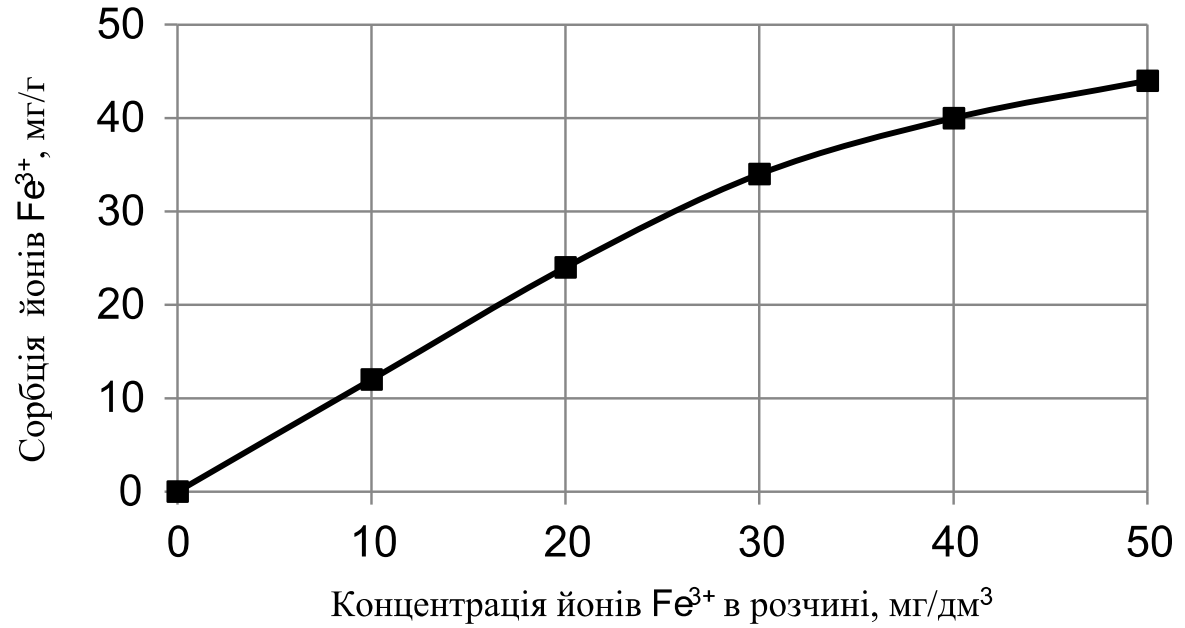

a)

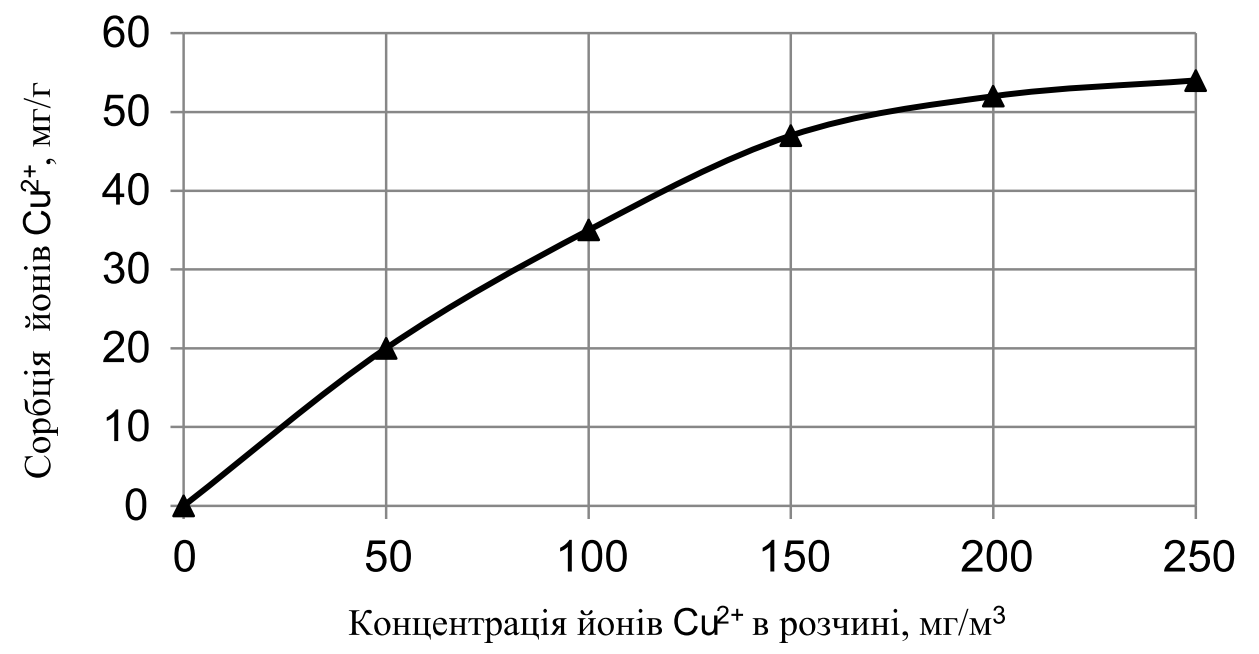

б)

Puc. 4. Залежність сорбції йонів $\mathrm{Fe}^{3+}$ (a) та $\mathrm{Cu}^{2+}$ (б) від їх концентрації в розчині

Аналізуючи одержані результати порівняно 3 літературними даними, можна стверджувати, що подрібнена шкаралупа кісточок абрикоса характеризується високою сорбційною здатністю щодо органічних i неорганічних токсикантів i не поступається (а навіть дещо перевищує) у своїй ефективності іншим рослинним сорбентам.

Висновки. Показана ефективність використання відходів харчової промисловості, зокрема шкаралупи кісточок абрикоса, для сорбції органічних і неорганічних речовин із водних розчинів.

Одержані результати можуть покладатися в основу розробки ефективної технології очистки стічних вод від органічних барвників та/або йонів важких металів 3 використанням дешевої та доступної 
природної сировини у вигляді відходів або побічних продуктів переробки сільського господарства та харчової промисловості й мати широке практичне значення. Такий підхід уможливить запровадити новий спосіб утилізації твердих рослинних відходів 3 метою зменшення екологічного навантаження на навколишнє середовище.

\section{СПИСОК ВИКОРИСТАНИХ ДЖЕРЕА}

1. Duruibe J. O., Agwuegbu M. O. C., Egwurugwu J. N. Heavy metal pollution and human biotoxic effects. Int. J. Phys. Sci. 2007. Vol. 2, N 5. P. 112-118.

2. Jaishankar M., Tseten T., Anbalagan N., Mathew B. B., Beeregowda K. N. Toxicity, mechanism and health effects of some heavy metals. Interdisciplinary Toxicology. 2014. Vol. 7, N 2. P. 60-72.

3. Aguiar J. E., de Oliveira J. C. A., Silvino P. F. G., Neto J. A., Silva I. J., Lucena S. M. P. Correlation between PSD and adsorption of anionic dyes with different molecular weights on activated carbon. Colloids and Surfaces A: Physicochemical and Engineering Aspects. 2016. Vol. 72, N 296. P. 125-131.

4. Aravind P., Selvaraj H., Ferro S., Sundaram M., Hazard J. An integrated (electro- and bio-oxidation) approach for remediation of industrial wastewater containing azo-dyes: Understanding the degradation mechanism and toxicity assessment. Mater. 2016. Vol. 318. P. 203-215.

5. Осокин В. М., Сомин В. А. Исследование по получению новых сорбентов из растительного сырья для очистки воды. Ползуновский вестн. 2013. № 1. C. 280-282.

6. Bazargan A., Tan J., Hui C. W., McKay G. Utilization of rice husks for the production of oil sorbent materials. Cellulose. 2014. N 21. P. 1679-1688.

7. Ozdemir I., Sahin M., Orhan R., Erdem M. Preparation and characterization of activated carbon from grape stalk by zinc chloride activation. Fuel. Process. Technol. 2014. Vol. 125. P. 200-206.

8. Николайчук А. А., Купчик Л. А., Картель Н. Т., Денисович В. О. Синтез и свойства биосорбентов, полученных на основе целлюлозно-лигнинового растительного сырья - отходов агропромышленного комплекса. Сорбционные и хроматографические процессы. 2007. Т. 7, Вып. 3. С. 489-498.

9. Оболенская A. В., Ельцина 3. П., Леонович А. А. Лабораторные работы по химии древесины и целлюлозы. М. : Экология, 1991. 320 с.

10. Кельцев Н. В. Основы адсорбционной техники. М. : Химия, 1976. 511 с.

11. Кореман Я. И. Практикум по аналитической химии. Воронеж : Изд-во Воронеж. ун-та, 1989. 225 с.

12. Kartel M., Galysh V. New composite sorbents for caesium and strontium ions sorption. Chemistry Journal of Moldova. 2017. Vol. 12, N. 1. P. 37-44.

13. Suteu D., Zaharia C., Badeanu M. Agriculture wastes used as sorbents for dyes removal from aqueous environments. Lucrări Stiiințifice. 2010. Vol. 53, N 1. P. 140-145.

14. Ong S. T., Keng P. S., Ooi S. T., Hung Y. T., Lee S. L. Utilization of fruits peel as a sorbent for removal of Methylene Blue. Asian. J. Chem. 2012. Vol. 24, N 1. P. 398-402. 
15. Surovka D., Pertile E. Sorption of iron, manganese, and copper from aqueous solution using orange peel: optimization, isothermic, kinetic, and thermodynamic studies. Pol. J. Environ. Stud. 2017. Vol. 26, N 2. P. 795-800.

16. Sheibani A., Shishehbor M. R., Alaei H. Removal of Fe(III) ions from aqueous solution by hazelnut hulas an adsorbent. International Journal of Industrial Chemistry. 2012. Vol. 3. P. 1-4.

17. Pehlivan E., Altun T., Parlayici Ş. Modified barley straw as a potential biosorbent for removal of copper ions from aqueous solution. Food. Chem. 2012. Vol. 135, N 4. P. 2229-2234.

18. Mathew B. B., Jaishankar M., Biju V. G., Beeregowda K. N. Role of bioadsorbents in reducing toxic metals. J. Toxicol. 2016. Vol. 12. P. 1-13.

19. Bsoul A. A., Zeatoun L., Abdelhay A., Chiha M. Adsorption of copper ions from water by different types of natural seed materials. Desalination and Water Treatment. 2014. Vol. 52. P. 5876-5882.

Стаття надійшла до редакиії 19.02.2018.

\section{Halysh V., Chykun N. Pasalskiy B. Sorption properties of the apricot kernel shell.}

Background. Biosorption is a promising process that can be used to remove pollutants from aqueous solutions using inexpensive sorbents based on vegetal waste from wood processing, pulp and paper industry and agriculture.

Promising is the use of sorbents of hard waste from the food industry, which are formed in significant volumes and do not find extensive practical use.

The aim of the work is to determine the chemical composition of the apricot kernel shell and to investigate their sorption capacity in the crushed state for synthetic dye and metal ions.

Material and methods. In this work apricot kernel shells crushed to a size of $0.5-1 \mathrm{~mm}$ were used. The chemical composition of the raw material, structural and sorption characteristics were determined using chemical analysis methods, infrared spectroscopy, porosimetry, and others. The sorption ability towards synthetic dye and heavy metal ions was studied using model solutions.

Results. The results of the determination of the chemical composition showed that the apricot kernels contained $24 \%$ of cellulose, $17 \%$ of hemicelluloses, $49 \%$ of lignin, $5 \%$ of substances extracted with alcohol-benzene mixture, $3 \%$ of mineral substances. The specific surface area of the apricot kernel shells is close and reaches 5 and $7 \mathrm{~m}^{3} / \mathrm{g}$, respectively, using nitrogen adsorption and mercury porosity methods. According to the results the methylene blue adsorption, the value of the specific surface was $27 \mathrm{~m}^{3} / \mathrm{g}$, which can be explained by the fact that fixation of the dye on the surface of plant materials occurs not only due to adsorption in pores, but also due to the chemical interaction of cations of dyes and functional groups of lignin and cellulose. The volume of adsorption pore according to benzene vapor sorption is very low and only $0.03 \mathrm{~cm}^{3} / \mathrm{g}$.

The study of the effect of the time of the sorption of methylene blue on its efficiency shows that the maximum absorption rate of the dye corresponds to the first 10 minutes of contact. Complete sorption equilibrium is achieved within 120 minutes. The sorption capacity of the crushed apricot kernel shells reaches $49 \mathrm{mg} / \mathrm{g}$, for $\mathrm{Fe}^{3+}$ and $\mathrm{Cu}^{2+}$ ions are 44 and $54 \mathrm{mg} / \mathrm{g}$, respectively. 
Conclusion. The efficiency of using food industry waste, in particular apricot kernel shells, for the sorption of organic and inorganic substances from aqueous solutions is shown.

The obtained results can be the basis for the development of an effective technology for the treatment of wastewater from organic dyes and/or heavy metal ions for the use of cheap and available natural raw materials such as waste or byproducts of agricultural and food industry, and can be of great practical importance.

This approach will allow the introduction of a new way to utilize solid vegetal wastes to reduce the environmental pollution of the environment.

Keywords: lignocellulose, dye, heavy metal ions, cellulose, lignin, sorption, sorption efficiency.

\section{REFERENCES}

1. Duruibe J. O., Agwuegbu M. O. C., Egwurugwu J. N. Heavy metal pollution and human biotoxic effects. Int. J. Phys. Sci. 2007. Vol. 2, N 5. P. 112-118.

2. Jaishankar M., Tseten T., Anbalagan N., Mathew B. B., Beeregowda K. N. Toxicity, mechanism and health effects of some heavy metals. Interdisciplinary Toxicology. 2014. Vol. 7, N 2. P. 60-72.

3. Aguiar J. E., de Oliveira J. C. A., Silvino P. F. G., Neto J. A., Silva I. J., Lucena S. M. P. Correlation between PSD and adsorption of anionic dyes with different molecular weights on activated carbon. Colloids and Surfaces A: Physicochemical and Engineering Aspects. 2016. Vol. 72, N 296. P. 125-131.

4. Aravind P., Selvaraj H., Ferro S., Sundaram M., Hazard J. An integrated (electro- and bio-oxidation) approach for remediation of industrial wastewater containing azodyes: Understanding the degradation mechanism and toxicity assessment. Mater. 2016. Vol. 318. P. 203-215.

5. Osokin V. M., Somin V. A. Issledovanie po polucheniju novyh sorbentov iz rastitel'nogo syr'ja dlja ochistki vody. Polzunovskij vestn. 2013. № 1. S. 280-282.

6. Bazargan A., Tan J., Hui C. W., McKay G. Utilization of rice husks for the production of oil sorbent materials. Cellulose. 2014. N 21. P. 1679-1688.

7. Ozdemir I., Șahin M., Orhan R., Erdem M. Preparation and characterization of activated carbon from grape stalk by zinc chloride activation. Fuel. Process. Technol. 2014. Vol. 125. P. 200-206.

8. Nikolajchuk A. A., Kupchik L. A., Kartel' N. T., Denisovich V. O. Sintez i svojstva biosorbentov, poluchennyh na osnove celljulozno-lignino-vogo rastitel'nogo syr'ja othodov agropromyshlennogo kompleksa. Sorbcionnye i hromatograficheskie processy. 2007. T. 7, Vyp. 3. S. 489-498.

9. Obolenskaja A. V., El'cina Z. P., Leonovich A. A. Laboratornye raboty po himii drevesiny i celljulozy. M. : Jekologija, 1991. 320 s.

10. Kel'cev N. V. Osnovy adsorbcionnoj tehniki. M. : Himija, 1976. $511 \mathrm{~s}$.

11. Koreman Ja. I. Praktikum po analiticheskoj himii. Voronezh : Izd-vo Voronezh. un-ta, 1989. $225 \mathrm{~s}$

12. Kartel M., Galysh V. New composite sorbents for caesium and strontium ions sorption. Chemistry Journal of Moldova. 2017. Vol. 12, N. 1. P. 37-44.

13. Suteu D., Zaharia C., Badeanu M. Agriculture wastes used as sorbents for dyes removal from aqueous environments. Lucrări Științifice. 2010. Vol. 53, N 1. P. 140-145.

14. Ong S. T., Keng P. S., Ooi S. T., Hung Y. T., Lee S. L. Utilization of fruits peel as a sorbent for removal of Methylene Blue. Asian. J. Chem. 2012. Vol. 24, N 1. P. 398-402. 
15. Surovka D., Pertile E. Sorption of iron, manganese, and copper from aqueous solution using orange peel: optimization, isothermic, kinetic, and thermodynamic studies. Pol. J. Environ. Stud. 2017. Vol. 26, N 2. P. 795-800.

16. Sheibani A., Shishehbor M. R., Alaei H. Removal of Fe(III) ions from aqueous solution by hazelnut hulas an adsorbent. International Journal of Industrial Chemistry. 2012. Vol. 3. P. 1-4.

17. Pehlivan E., Altun T., Parlayici Ş. Modified barley straw as a potential biosorbent for removal of copper ions from aqueous solution. Food. Chem. 2012. Vol. 135, N 4. P. 2229-2234.

18. Mathew B. B., Jaishankar M., Biju V. G., Beeregowda K. N. Role of bioadsorbents in reducing toxic metals. J. Toxicol. 2016. Vol. 12. P. 1-13.

19. Bsoul A. A., Zeatoun L., Abdelhay A., Chiha M. Adsorption of copper ions from water by different types of natural seed materials. Desalination and Water Treatment. 2014. Vol. 52. P. 5876-5882. 